\title{
Investing in the environment: Some thoughts on the new breed of green hedge funds
}

\author{
Paul Ali \\ Faculty of Law, University of Melbourne, Parkville VIC 3010, Australia. \\ Tel: + 6138344 1088; E-mail: p.ali@unimelb.edu.au \\ Received (in revised form): 18th September, 2006
}

Paul Ali SJD is an associate professor of Law at the University of Melbourne. He has previously worked as a finance lawyer in Sydney. He is the author of several books and articles on finance and investment law, including 'Corporate Governance and Investment Fiduciaries' (Sydney, 2003) which examines the corporate governance aspects of mutual funds and hedge funds.

\section{Practical applications}

This paper provides an overview of the legal structure of green or environmental hedge funds and an analysis of the funds in the context of the prudent investor rule. That is likely to be of considerable interest to the promoters of the fund and potential investors. The paper also provides the basis for further empirical research into this new class of hedge funds and, more generally, the investment outcomes from the pursuit of environmentally oriented or socially responsible investment strategies.

\begin{abstract}
Hedge funds have now begun to expand into the field of ethical or socially responsible investment. Among the latest entrants into that field are green or environmental hedge funds that seek absolute returns from environmentally oriented investment strategies. This paper examines the legal structure of these new environmental hedge funds and the implications for them of the prudent investor rule. An analysis of that rule discloses that care must be taken in designing security screens and selecting investments for environmental hedge funds to address the potential tension between the financial criteria for investment stipulated by the prudent investor rule and the non-

financial environmental objectives or philosophy of the fund.

Derivatives Use, Trading \& Regulation (2007) 12, 351-357. doi:10.1057/palgrave.dutr.1850055
\end{abstract}

Derivatives Use, Trading \& Regulation, Vol. 12 No. 4, 2007, pp. 351-357 C 2007 Palgrave Macmillan Ltd 1357-0927\$30.00
Keywords: hedge funds; environmental investment; prudent investor rule

\section{INTRODUCTION}

The widespread support for measures to address global warming and reduce pollution, such as the Kyoto Protocol to the United Nations Framework Convention on Climate Change, and the increasing preoccupation of businesses and the broader public with environmental matters have, unsurprisingly, created an appetite among investors for investment products that can deliver superior returns while adhering to an environmentally friendly philosophy. In this context, the recent emergence of a new class of green or environmental hedge funds is a natural incident 
of the increasing popularity of socially responsible mutual funds.

Indeed, many of these environmental hedge funds have adopted the investment techniques developed by mutual funds, to select investments either on the basis of specific environmental criteria or as part of a comprehensive set of criteria embodying the broader socially responsible objectives or philosophy of the fund. An environmental hedge fund recently launched by the Winslow Management Company is a useful example of the former, where equity securities are selected for investment by the fund by reference primarily to specific environmental criteria. Other hedge funds, such as those managed by Gabelli Asset Management Company and Green Cay Asset Management, exemplify the latter approach where more broadly based socially responsible criteria have been adopted to select investments.

Coupled with these funds are hedge funds, such as the carbon offset fund managed by Cheyne Capital Management and Climate Wedge, which are dedicated to generating investment returns from the new class of carbonbased financial instruments that have emerged in the wake of the Kyoto Protocol. ${ }^{1}$ Hedge funds now account for an increasing share of trading volumes in carbon markets worldwide, including the European Union Emissions Trading Scheme Market and the European Climate Exchange. 2,3

This paper provides an overview of the legal structure of environmental hedge funds and the security screening techniques employed by many of these funds and also examines environmental hedge funds in the context of the prudent investor rule that applies to all fiduciary investment vehicles.

\section{INVESTMENT SELECTION}

The investment selection techniques employed by many environmental hedge funds are the same as those pioneered by more conventional collective investment vehicles such as mutual funds that follow environmentally oriented or socially responsible investment strategies. In both cases, the fund's portfolio is constructed using a screen to create a universe of investable securities. ${ }^{4}$

Two types of security screens - negative and positive screens - are used, with the former being the more common. A negative screen operates by limiting the securities or other financial instruments in which an environmental hedge fund may invest, by excluding from the investable universe for the fund those securities or instruments that have been issued by corporations, for example, whose activities are viewed as causing damage to the environment, which are major emitters of greenhouse gases or which have a poor track record in terms of compliance with environmental standards. ${ }^{5}$

Positive screens, in contrast, are used to create an investable universe for the fund by selecting securities or other instruments issued by corporations which are viewed as environmentally responsible, such as corporations that have taken significant steps to reduce their greenhouse gas emissions or promote the use of recycled materials and the generation of energy from renewable sources. ${ }^{6}$

More recently, environmental hedge funds have been launched that employ a 'best-in-class' variation to such vanilla positive screens. Securities or other instruments are selected for inclusion in the fund's portfolio by reference not to absolute criteria but as to how well a particular corporation has performed, as regards compliance with environmental standards or the 
adoption of environmentally friendly policies, relative to its industry peers. ${ }^{7}$ Accordingly, the securities of a corporation that might be rejected by a negative screen or fail the criteria for inclusion set by a conventional positive screen may nonetheless form part of the investable universe for an environmental hedge fund using a best-in-class screen due to the business practices of that corporation compared to that of its peers.

\section{STRUCTURAL FEATURES OF ENVIRONMENTAL HEDGE FUNDS}

Despite the fact that many environmental hedge funds use the same screening techniques as other collective investment vehicles that follow environmentally oriented investment strategies, there are important structural differences between the two groups. The key differences relate to their disparate performance goals, the techniques employed to derive returns from the securities and other financial instruments that make up the hedge fund's investable universe, investor issues, the remuneration and dual capacity of the hedge fund manager as investor, and the jurisdictional bifurcation of the hedge fund ${ }^{8}$

(i) Environmental hedge funds, like all hedge funds, seek absolute returns. ${ }^{9}$ In contrast, other environmental investment funds seek relative performance (the performance objectives may reference a broad market benchmark, an index that provides a proxy for the fund's investment strategy or a peer group of investment funds).

(ii) Environmental hedge funds enjoy considerable flexibility in terms of how they implement their investment strategies and, in particular, are subject to few constraints on their use of leverage or derivatives to boost returns and their taking of concentrated and short positions. Other environmental investment funds, in contrast, are more restricted in the asset classes that they can invest in (for example, the authorised asset classes may comprise only cash and securities that have passed an environmental screen), and may be permitted to borrow only for settlement purposes and the financing of redemptions, unable to use derivatives other than for hedging purposes, subject to concentration limits and prohibited from taking short positions.

(iii) Environmental hedge funds are marketed to high net-worth individuals and institutional investors. Unlike other environmental investment funds, retail investors are not usually able to invest directly in environmental hedge funds, although they may be able to invest indirectly via a fund of funds that itself invests in environmental hedge funds.

(iv) Environmental hedge funds typically impose strict limits on investor entry and exit, making them significantly less liquid than other environmental investment funds. Investors may only be able to subscribe for interests in an environmental hedge fund during the initial offer period and redeem their interests in the fund during specified entry windows (and normally after a stipulated lock-up period has expired and advance notice of intention to withdraw from the fund has been given).

(v) The fees levied by the manager of an environmental hedge fund are 
performance-based (the manager receives a

fixed management fee as well as performance fee typically comprising 20-40per cent of the fund's performance above a stipulated threshold) and the manager will usually be a significant investor in the hedge fund itself.

(vi) Environmental hedge funds often straddle two jurisdictions. While the manager of the hedge fund will normally be located in a major financial centre, the fund itself may have been formed in a lightly regulated, low-tax jurisdiction (for obvious reasons).

\section{BALANCING ENVIRONMENTAL AND INVESTMENT GOALS}

Environmental hedge funds are fiduciary investment vehicles. This is a characteristic they share with mutual funds and other collective investment vehicles, regardless of the legal structure of the hedge fund and the widely framed or relatively unfettered investment powers of the hedge fund manager. Such vehicles invest not for their own account, but for the benefit of third parties - the investors in the fund - and that fact entails certain duties at law, including the duty on the part of the fund and its manager to ensure that investments are selected in a prudent manner within the parameters set by the fund's investment strategy. ${ }^{10}$

This requirement - the so-called prudent investor rule - applies to environmental hedge funds in common law jurisdictions, including the major on-shore hedge fund markets of the United States and the United Kingdom (as well as the hedge fund markets of Australia, Canada, Hong Kong and Singapore) and the key offshore domiciles for hedge funds of the Bahamas,
Bermuda, the British Virgin Islands and the Cayman Islands.

There are two aspects to this prudent investor rule. First, the fund must actually invest the assets (typically, cash but, in some instances, in-kind investments) entrusted to it. ${ }^{11}$ This aspect of the prudent investor rule is simply a restatement of the core function of all collective investment vehicles, and is self-evident and uncontroversial for the vast majority of collective investment vehicles.

There, however, is potential for conflict, in the case of collective investment vehicles, such as environmental hedge funds that follow environmentally oriented investment strategies, between what the prudent investor rule perceives as the core function of a fund and what the fund has adopted as its overarching objectives or philosophy. While it is entirely proper for those objectives or that philosophy (for instance, promoting sustainable development or combating global warming) to inform the selection of investments, the investment function of the fund cannot be subordinated to such objectives or philosophy.

Investment entails the acquisition of assets capable of generating financial returns (within a level of risk acceptance for the particular fund). The use of the fund's assets for non-investment purposes (such as the financing of an environmental campaign) is a clear violation of the prudent investor rule but so too is the selection of investments on a basis that gives priority to the environmental objectives or philosophy of the fund over the fund's return objectives. For example, an environmental hedge fund is free to exercise the voting rights attached to shares acquired by it, to requisition or support environmentally friendly resolutions (or to vote against resolutions viewed as 
unfriendly to the environment or antagonistic to the fund's philosophy). However, the acquisition of such shares (or other investments) must primarily be to generate financial returns for the fund and its investors as opposed to providing an avenue for the promotion of the fund's philosophy.

The second aspect of the prudent investor rule concerns the requirements for investment suitability and portfolio diversification. ${ }^{12}$ The two requirements are well summarised in the 1994 Uniform Prudent Investor Act:

(vii) The purposes, terms, distribution requirements and other material circumstances of the fund must be taken into account when selecting investments.

(viii) Investments must be selected having regard to the fund's portfolio as a whole and as part of the fund's investment strategy. The factors to be taken into account include the role of a particular investment within the fund's portfolio, the expected total return from the investment, and the needs of the fund for liquidity, regularity of income and the preservation or appreciation of capital.

(ix) The fund's investments must be diversified.

That Act has been adopted in the majority of States in the United States (in the remaining States, principles consistent with the above requirements have been enshrined in case law). ${ }^{13}$ Equivalent requirements apply in the United Kingdom and, for instance, in the majority of the Canadian common law provinces and, arguably, Australia. ${ }^{14}$

The requirements for investment suitability and portfolio diversification reinforce the investment role of collective investment vehicles by establishing guidelines for the selection of investments. Importantly, whether an investment should be included in the fund's portfolio is not to be determined by reference only to that investment and its individual attributes, such as its riskiness, but, instead, by examining the impact of the investment on the overall return and riskiness of the fund's portfolio and the investment's contribution to portfolio diversification. This whole-of-portfolio approach to investment selection is predicated upon modern portfolio theory. $^{15}$

Again, for hedge funds and other collective investment vehicles pursuing conventional investment strategies, the above requirements are unlikely to be controversial. However, for environmental hedge funds, as with the first aspect of the prudent investor rule, the second aspect carries the potential for tension between the financial imperatives of the prudent investor rule and the overarching environmental (that is, non-financial) objectives or philosophy of the fund. An environmental hedge fund cannot sacrifice compliance with the requirements for investment suitability and portfolio diversification to the pursuit of the fund's non-financial objectives or philosophy.

A balance must, instead, be drawn between the financial imperatives of the prudent investor rule and the (non-financial) environmental objectives or philosophy of an environmental hedge fund. ${ }^{16}$ Thus, while an environmental hedge fund (or other collective investment vehicle following an environmentally oriented investment strategy) will seek investments that are consistent with the fund's non-financial objectives or philosophy, any investments selected must be capable of being justified by reference to the financial criteria relating to the 
suitability of the investment and the need for portfolio diversification.

In addition, the use of security screens to create an investable universe means that an environmental hedge fund employing such a screen will necessarily have available to it fewer securities or financial instruments for inclusion in its portfolio than a conventional hedge fund with comparable risk and return parameters. This may undermine the ability of the hedge fund manager to select suitable investments and diversify the fund's portfolio as required by the prudent investor rule. ${ }^{17}$ Accordingly, care must be taken to ensure that the design of the security screen does not, itself, involve a subordination of the requirements of the prudent investor rule to the non-financial objectives or philosophy of the fund.

\section{CONCLUSION}

Hedge funds have now begun to enter the market for environmentally friendly or socially responsible investment products. This development is likely to find considerable favour with the pension funds that are among the largest providers of capital to hedge funds as well as other important capital providers such as academic endowments and charitable foundations. In addition to addressing the changing appetites of their investors, hedge fund managers have been able to use these hedge funds to derive returns by exploiting the pricing and other inefficiencies that characterise the new markets in carbon-based financial instruments. ${ }^{18}$

Although environmental hedge funds embody the structural features common to all hedge funds, they face one issue not commonly encountered by their more conventional counterparts in the hedge fund world. This is the need to address the potential tension between the financial criteria for investment as expressed in the prudent investor rule and the nonfinancial environmental objectives or philosophy that drives environmental hedge funds. This issue is by no means unique to environmental hedge funds - it is encountered, for instance, by mutual funds that follow socially responsible investment strategies and also by hedge funds whose investment strategies are oriented towards corporate governance. ${ }^{19}$

This tension is absent where the only difference between an environmental hedge fund and more conventional hedge funds is the asset classes that they invest in. Both are equally motivated by the desire to generate absolute returns by reference only to financial criteria. However, for those environmental hedge funds that invest in conventional asset classes, such as equity securities, by reference to environmental - that is, non-financial - criteria, the selection of investments and the pursuit of investment returns in accordance with the financial criteria of the prudent investor rule (where primacy is given to investment suitability and portfolio diversification) cannot take second-place to the pursuit of the fund's non-financial goals as expressed in its environmental criteria. In addition, in setting the environmental criteria for the inclusion or exclusion of potential investments, care must be taken to ensure that those criteria are not framed in such a way as to undermine the fund's ability to comply with the prudent investor rule.

Equally, participation by a hedge fund in the new carbon markets will not satisfy the strictures of the prudent investor rule where the fund's participation is primarily motivated not by the desire to derive investment returns but by the fact that the rationale for such markets (typically, 
the reduction of greenhouse gas emissions) accords with the environmental objectives or philosophy of the fund.

\section{References}

1 Ali, P. U. and Yano, K. (2004) 'Eco-Finance: The Legal Design and Regulation of Market-Based Environmental Instruments', Kluwer Law International, The Hague, pp. 43-60.

2 Capoor, K. and Ambrosi, P. (2006) 'State and Trends of the Carbon Market 2006', World Bank and International Emissions Trading Association, pp. 6, 16, 26 and 37.

3 Fusaro, P. C. and Vasey, G. M. (2006) 'Energy \& Environmental Hedge Funds', John Wiley \& Sons, Singapore, pp. 125-128.

4 Hallerbach, W., Ning, H., Soppe, A. and Spronk, J. (2004) 'A Framework for Managing a Portfolio of Socially Responsible Investments', European Journal of Operational Research, Vol. 153, pp. 517-529.

5 Ali and Yano, supra, pp. 126-128.

6 Ibid.
7 O'Rourke, A. (2003) 'The Message and Methods of Ethical Investment', Journal of Cleaner Production, Vol. 11, pp. 683-693.

8 Ali and Yano, supra, pp. 144-146.

9 Ineichen, A. M. (2003) 'Absolute Returns', John Wiley \& Sons, Hoboken, NJ, pp. 19-20 and 98.

10 Ali, P. U., Stapledon, G. and Gold, M. (2003) 'Corporate Governance and Investment Fiduciaries', Lawbook Co., Sydney, pp. 76-78.

11 Ibid.

12 Ibid.

13 Ali and Yano, supra, pp. 137-138.

14 Ibid, pp. 134-139.

15 Ali, Stapledon and Gold, supra, pp. 82-95.

16 Ali and Yano, supra, pp. 140-141.

17 Ali, P. U. (2006) 'Corporate Social Responsibility and Fiduciary Investment in Australia', in Ali, P. U., and Gregoriou, G. N. (eds.), 'International Corporate Governance after Sarbanes-Oxley', John Wiley \& Sons, Hoboken, NJ, p. 169.

18 Fusaro and Vasey, supra, pp. 127-128.

19 Kahan, M. and Rock, E. B. (2006) 'Hedge Funds in Corporate Governance and Corporate Control', Working Paper, Institute for Law and Economics, University of Pennsylvania. 